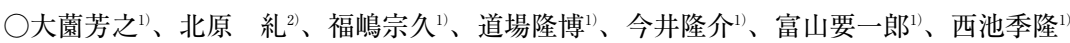

大阪労災病院 耳鼻咽喉科 ${ }^{11}$ 、大阪大学 耳鼻咽喉科・頭頸部外科学 ${ }^{22}$

めまいは内耳由来の耳性めまいを始め、脳幹等の中枢由来、心疾患等の循環器系由来等と、原因となる臟器は多岐にわた る。今回われわれは救急外来におけるめまい患者の内訳、および得られた問診事項／検查事項の結果と、最終的に下された めまい疾患の確定診断名、中枢性／非中枢性との相関を検索した。平成 23 年 4 月から平成 24 年 3 月までに、大阪労災病院救 急外来で受け入れた全めまい疾患 120 例を対象とした。救急外来対応時に、患者問診事項、検查処置対応をフロー・チャー トにまとめ、全めまい症例に対して施行することとした。また必要に応じて、当院耳鼻咽喉科にて純音聴力検査、温度刺激 検查により内耳機能を評価し、めまい疾患の確定診断を下した。全めまい疾患120例の内訳は、耳性めまい疾患90例、中枢 血管障害15例、その他中枢性 1 例、血圧調節障害 4 例、片頭痛性めまい 2 例、めまい症 8 例であった。基礎疾患（高血圧、 糖尿病、高脂血症）のある患者は有意に中枢性の可能性が高く、また問診事項、検査結果の主な項目では注視眼振が単変 量、多変量解析共に有意であった。

\title{
50 市中病院における入院を要しためまい疾患の臨床的検討
}

高田大輔 ${ }^{122}$ 、伊藤博之 ${ }^{22}$ 、北村剛一2)、船戸宣利 ${ }^{2} 、$ 鈴木 衞 $^{2}$

西東京中央総合病院 耳鼻咽喉科 ${ }^{11}$ 、東京医科大学 耳鼻咽喉科 ${ }^{2)}$

今回われわれは2011年 4 月〜2012年11月までに西東京中央総合病院耳鼻咽喉科に入院を要しためまい症例127名、140症例 について検討した。性別は男性50例、女性77例であった。年齢は23歳から92歳で、平均年齢は67.8歳で、70歳代が39例で最 も多かった。疾患は良性発作性頭位めまい症（BPPV）が40例と最も多く、メニエール病35例、前庭神経炎25例、分類不能 の内耳性めまい23例、突発性難聴 7 例、脳梗塞 4 例、ハント症候群 1 例で、眼振のなかった症例は 5 例であった。救急搬送 された症例は70例であった。再入院症例は 13 例あったが、中には最初の入院で BPPV と診断され、一旦症状が軽快して退 院したものの、 2 度目の入院で脳梗塞と診断されたものが 1 例あった。これまでに報告されためまいに関する統計は、大学 病院など十分な平衡機能検査を行える施設の外来受診例に関するものが多く、急性期疾患に遭遇する機会の多い市中病院に 損いて、かつ入院を要しためまい症例に関する統計は少ないため、今回の検討で市中病院のめまい疾患を診断するための問 題点を検討することができた。

\section{1 東京医科歯科大学における CTP 検査施行症例の検討}

○丸山絢子(1)2 、野口佳裕2)、西尾綾子 ${ }^{2}$ 、高橋正時2)、池園哲郎 ${ }^{3)}$ 、喜多村 健 $^{22}$

武蔵野赤十字病院 耳鼻咽喉科 ${ }^{12}$ 、東京医科歯科大学 耳鼻咽喉科 ${ }^{2}$ 、埼玉医科大学 耳鼻咽喉科 ${ }^{3)}$

CTP は外リンパ瘦 (PLF) 診断のマーカーであり、PLF 診断基準 (案) で基準項目の1つに挙げられる。今回われわれは、 2011年12月から2012年 8 月の間に東京医科歯科大学耳鼻咽喉科で ELISA 法による CTP 検查を施行した 4 例を検討した。

症例 1 （54歳女性）は聴力正常の難治性浮動性めまいで歩行困難となり入院。発症 7 力月後に両耳検査を行い左陽性であ った。内耳空閉鎖術でめまいは治癒した。症例 2 （73歳男性）と症例 3 （43歳女性）はくしゃみおよび潜水後の急性感音難 聴例で、それぞれ発症21日後、11日後の術中中耳洗浄液で陽性を示した。症例 3 は前庭空の瘦孔が確認され、術後聴力も回 復した。症例 4 （61歳女性）は鼻かみ後の左進行性感音難聴例であり、発症後 1 年の検查が陰性であったため手術は行わな かった。

くしゃみ、潜水後の PLF の存在は欧米では否定的な見解があるが、今回の検查結果はこれら介達外力による PLF の存在 を示唆するものであった。また本検査は、原因不明のめまいの診断・患側の決定、治療方針の決定にも有用であった。

\section{2 当科における外リンパ瘻症例の検討}

○武田早織、竹井 慎、河野正充、戸川彰久、保富宗城、山中 昇 和歌山県立医科大学 耳鼻咽喉科・頭頸部外科

はじめに: 外リンパ瘦は早期の手術治療によって、速やかな聴力の回復が期待できる疾患であるが、診断に難渋すること も多い。成績を左右する因子としては、Otological emergency として手術的瘦孔閉鎖の判断をいかに早く行うかがポイント と考えられる。対象と方法：2005年 5 月から2012年 6 月に外リンパ瘦と診断した23例を対象とし、症状、治療法、治療成績 などについて検討した。結果・考察: 性別は男性10例、女性13例、年齢は 7 93歳（平均45歳）、患側は右側 9 例、左側13 例、両側性 1 例であった。外リンパ瘦診断の確実例は 9 例、疑い例は14例であった。原因は内因性圧外傷と、原因不明であ る例が多かった。23例中、20例に手術を行った。初診時の聴力は $90 \mathrm{~dB}$ 以上の重症例が多く、高度難聴である症例で、聴力 予後は不良であった。諸家の報告では聴力の改善は 20 70\%と様々であるが、当科では $60 \%$ の改善率であり、発症後平均 6 日目と早期に手術を施行していることが奏功していると考えられた。 
○森 学、近澤仁志、谷口雄一郎、小島博己、森山 寛 東京慈恵会医科大学 耳鼻咽喉科学教室

外リンパ瘦は日常診療においてしばしば経験する疾患である。しかし、原因が明確でない特発性外リンパ瘦は臨床症状の 多様性に加え、手術で初めて確定診断が下されるという特徵から治療法の選択が困難になっている。

外リンパ瘦は発症から手術までの期間が短いほど聴力が改善しやすいことが多く報告されているが、保存的治療から手術 治療へ移行する時期については明確な指針がない。また、保存的加療を行った症例との聴力やめまいなどの比較検討はなさ れてない。

今回われわれの施設での最近 2 年間における外リンパ瘦疑い（急性感音難聴発症後に聴力変動を認めた症例）のうち、手 術治療をした 7 症例と保存的治療を選択した 4 症例の臨床経過について比較検討を行った。

保存的治療群では治癒例は 1 例も認めなかった。一方、手術治療群においては術後に合併症を認める症例は扔らず治癒例 も存在した。これらの事から外リンパ瘦を疑う場合には、より早期に手術治療を行うことがより良い聴力予後につながる可 能性があると考えられた。

\section{4 当院における外リンパ瘻症例の検討、誘因の有無を比較して}

○小林賀子 ${ }^{122)}$ 、萩原 晃 ${ }^{122}$ 、齊藤 雄 ${ }^{122}$

厚生中央病院 耳鼻咽喉科 ${ }^{1)}$ 東京医科大学 耳鼻咽喉科 ${ }^{2)}$

外リンパ瘦は試験的鼓室開放以外に確立した確定診断方法がない。発症から手術までの期間が短いほど聴力が改善しやす いことが報告されており、早期診断が重要となる。典型的な誘因がない例では診断に難渋し、治療に抵抗する突発性難聴と して経過観察され、手術までの期間が長期になる例や手術時期を逸してしまう例も少なくないと考える。早期診断のために は注意深い問診を行い、いくつかの検査所見と併せて外リンパ㾇をまず疑うことが重要である。今回われわれは誘因の有無 を比較し当院で経験した外リンパ瘦を検討した。2010年 1 月から 2012 年10月に当院で加療した外リンパ瘦確実例 9 例を対象 とした。年齢分布は19歳から 65 歳、平均年齢は 44.8 歳、男性 6 例、女性 3 例で、誘因がある例は 5 例、誘因がない例は 4 例 だった。誘因がない例の初診時の聴力は全例 $70 \mathrm{~dB}$ 以上で重症であった。誘因がない 2 例で変動する難聴があり、突発性難 聴として複数回の治療を受けていた。全例で患側耳向きの眼振があり、2 例で瘦孔症状があった。

\section{5 突発性難聴として治療され、後に外リンパ㾞と判明した 2 症例についての検討}

○中原はるか、小宮山櫻子、若山貴久子、室伏利久 帝京大学 医学部附属溝口病院耳鼻咽喉科

（症例 1 ）58歳女性。51歳時、数日前からの難聴で紹介受診、鼓膜正常で左難聴を認め、ステロイド内服で軽快した。53 歳時、右耳の聴力低下で受診、この際には右低音部の聴力低下を認め、右突発性難聴として、入院加療した。58歳時、難聴 の悪化で受診、両側混合難聴を認め、耳硬化症を考え、より聴力の悪い左耳の手術を施行した。手術所見では、アブミ骨の 奇形と、底板よりの外リンパ漏出を認めた。(症例 2 ) 29 歳男性。マルファン症候群で、胸部大動脈瘤に対して、人工弁 ・ 人工血管置換術施行されている。それまで難聴はなかったが、入浴後に突然難聴になり、翌朝めまいが出現し紹介受診した。 右壟型の感音難聴を呈し、突発性難聴として入院加療をしたが、真珠腫を疑わせる所見を認めた。保存的治療で聴力改善乏 しく、手術を施行した。底板よりの外リンパ漏出を認めた。2症例の経過・問題点について考察する。

\section{6 体位変換にて聴力変動を認めた外リンパ瘻症例}

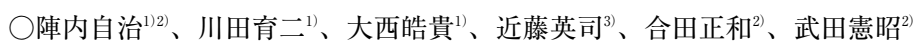

阿南共栄病院1 、国立病院機構 高知病院 ${ }^{2)}$ 、徳島大学耳鼻咽喉科 ${ }^{3)}$

強く鼻をかむことにより外リンパ瘦を生じた症例を経験した。本症例は短期間に聴力が変動し、機能性難聴との鑑別が非 常に困難であったが、体位変換聴力検査を施行し明らかな閾值変化を捉えることができた。仰臥位によって検査をする聴覚 検査と、座位で行う聴覚検査にあきらかな聴力閾值乘離が生じたため、座位聴力検査ののち、仰卧位聴力検査を施行した。 わずか 5 分で、閾值上昇がみられ聴力変動は体位によって生じると考えられた。考察) 外リンパ瘦は多彩な聴力検査所見を 呈するとされているため、機能性難聴や突発性難聴と鑑別を要する際、仰卧位聴力検査は施行する価值のある重要な検查に なりうると考えられる。 


\title{
57 滲出性中耳炎治療中に発症した外リンパ瘻確実症例
}

\author{
○杉崎一樹、松田 帆、新藤 晋、池園哲郎、加瀬康弘
}

埼玉医科大学 耳鼻咽喉科

【症例】66歳男性【主訴】めい【現病歴】右滲出性中耳炎を繰り返し、近医耳鼻科にて加療していた。通気治療翌朝に ふらつくようなめまいが出現した。その後も、動くたびにめまいが出現し、某病院から外リンパ瘦疑いで当科へ紹介され た。初診時、右鼓膜に液体貯留あり、鼓膜ドレーン挿入を行った。吸引した粘調な液体は CTP 陰性、貯留液除去後採取し た洗浄液は CTP 陽性であった。ドレーン挿入後約 2 週間後、鼓膜ドレーンより採取した中耳洗浄液も CTP 陽性であった。 この結果から、外リンパが持続的に漏出する右外リンパ瘦確実例と診断した。【手術所見】右試験的鼓室開放術を施行し た。正円空より漿液性の液体が持続的に渗み出てきた。同部位と卵円空を筋膜で被覆した。【術後経過】めまいの自覚は術 後 2 日目から改善した。その後外来で、眼振検査・めまい自覚症状 (VAS) ・重心動摇検査で経過を追っている。

\section{8}

\section{当科における過去 7 年間の両側同時性耳下腺良性腫瘍症例の検討}

○井口広義、和田匡史、松下直樹、寺西裕一、山根英雄

大阪市立大学 大学院医学研究科 耳鼻咽喉病態学

両側耳下腺に同時性の良性腫瘍が認められる場合、その大部分は両側ワルチン腫瘍の症例である。今回、2005年 1 月から 2011年12月までの過去 7 年間に、大阪市立大学医学部附属病院耳鼻咽喉科において腫瘍摘出術を行い、病理組織診断にて確 定診断を行った両側同時性耳下腺良性腫瘍症例（副耳下腺を含む）について検討を行ったので報告する。当該期間における 耳下腺良性腫瘍患者は158例（患側は173側）で、14例（8.9\%）が両側同時性発生であった。このうちの1例では、両側に 同組織の腫瘍および片側に異組織の腫瘍が存在したため 3 側と数えた。腫瘍組織別では、多形腺腫89例（89側）、ワルチン 腫瘍65例（78側）、オンコサイトーマ4 例（4側）、筋上皮腫 2 例（2 側）であった。14例の両側同時性腫瘍の組織別組み合 わせでは、両側ワルチン腫瘍が13例（うち1例は両側ワルチン腫瘍と片側多形腺腫）と大部分をしめ $(92.9 \%$ )、多形腺腫 と筋上皮腫が 1 例であった。左右異組織の症例提示とともに、若干の文献的考察を加えて報告する。

\section{9 再発耳下腺多形腺腫38症例の検討}

○桑内麻也子、一瀬和美、鯨井桂子、前田恭世、吉原俊雄

東京女子医科大学 耳鼻咽喉科

耳下腺多形腺腫は耳下腺腫瘍の組織型の過半数を占める良性腫瘍である。腫瘍の発育は緩徐な場合が多く、数十年かけて 発育するものもある。経過途中に悪性転化を伴う可能性は否定できないが、多くは良性のまま経過する。多形腺腫はその被 膜の脆弱性から、手術時に細胞播種があったり、特に播種しやすい組織型である場合手術後の再発率は高くなる。1989年 1 月から2012年11月までの23年11力月の間に当科において治療した再発耳下腺多形腺腫は38例である。初回手術はすべて他院 で行われており、男性12例、女性26例、初回手術年齢は12歳〜 59歳であり、当院での手術時の年齢は19歳〜79歳であった。 当院での手術が初回の再発例は23例、 2 回目の再発は 7 例、 3 回目の再発は 5 例、4 回以上の再発は 2 例であった。再発様 式として多発のものが31例、単発のものが 7 例であったが、このうち当院手術による病理検査で悪性転化していたものは 5 例であった。当科での症例について検討し、考察する。

\section{0 唾液腺多形腺腫における再発様式の臨床病理学的検討}

○白土秀樹1)、野田哲平 ${ }^{11} 、$ 瀬川祐一 ${ }^{1)}$ 、玉江昭裕 ${ }^{11} 、$ 中野貴史 ${ }^{2)}$ 、西嶋利光 ${ }^{2}$

国家公務員共済組合連合会 浜の町病院 耳鼻咽喉科 ${ }^{11}$ 、九州大学 医学部 形態機能病理学 ${ }^{2}$

多形腺腫は唾液腺良性腫瘍の中で最多であり生物学的には良性であるが、手術後再発を来したり、繰り返す再発経過中に 悪性化（carcinoma ex pleomorphic adenoma）を来すことも有る故、初回治療で治療経過を予測することは治療上有用であ ると考えられる。当科で1992年から2012年までの20年間に治療した耳下腺および顎下腺原発多形腺腫112例に対し、臨床病 理学的に検討した。また、再発症例、悪性化症例については再発様式、再発腫瘍の病理学的特徴、再発までの期間、術中所 見などについて検討したので報告する。 